\title{
Antimicrobial properties of silver nanoparticles against biofilm formation by Pseudomonas aeruginosa on archaeological textiles
}

\author{
Katarzyna Pietrzak $^{1^{*}}$, Anna Otlewska ${ }^{1}$, Michał Puchalski ${ }^{2}$, Beata Gutarowska ${ }^{1}$ and Patricia \\ Guiamet $^{3,4}$ \\ ${ }^{1}$ Institute of Fermentation Technology and Microbiology, Lodz University of Technology, Wólczańska 171/173, 90-924 \\ Łódź, Poland \\ 2 Department of Material and Commodity Sciences and Textile Metrology, Lodz University of Technology, Żerom- \\ skiego 116, 90-924 Lodz, Poland \\ ${ }^{3}$ Research Institute of Theoretical and Applied Physical Chemistry (INIFTA), Department of Chemistry, Faculty of Pure \\ Sciences, University of La Plata, UNLP, CCT La Plata-CONICET. CC.16, Suc 4, La Plata, Buenos Aires, Argentina \\ ${ }^{4}$ Faculty of Veterinary Sciences, UNLP, Argentina
}

\begin{abstract}
The aims of this work were to: (i) microscopically analyse the pre- and post-Columbian archaeological textiles using Scanning Electron Microscopy with Energy Dispersive X-Ray Analysis (SEM-EDX); (ii) microbiologically analyse the archaeological textiles (from the Southern Andean Area, La Plata Museum); (iii) determine the ability of Pseudomonas sp. isolates from archaeological textiles to biofilm formation by SEM; (iv) assess the anti-biofilm properties of AgNPs protecting cotton against Pseudomonas sp. Results showed the presence of bacteria with proteolytic and lipolytic activities on archaeological textiles, including Clostridium sp. and Pseudomonas aeruginosa. Two nucleotide sequences of $16 \mathrm{~S}$ ribosomal RNA gene of P. aeruginosa strains were deposited in GeneBank NCBI database with accession numbers: KP842564 (strain 1) and KP842565 (strain 2). Those strains exhibited different morphological and growth characteristics: strain 1 with ability to form biofilms on archaeological textiles was rod-shaped, produced bluish-green pigment, and smaller than strain 2; and strain 2 was pleomorphic and produced brown pigment. The use of silver nanoparticles $(90 \mathrm{ppm}, \phi 10-80 \mathrm{~nm}$ ) allowed to protecting textiles against $P$. aeruginosa growth by $63 \%-97 \%$, depending on the strain and exposition time.
\end{abstract}

Keywords: archaeological textiles, Pseudomonas sp., protection, silver nanoparticles, biofilm, SEM-EDX

*Correspondence to: Katarzyna Pietrzak, Institute of Fermentation Technology and Microbiology, Lodz University of Technology, Wólczańska 171/173, 90-924 Łódź, Poland; E-mail: khpietrzak@gmail.com

Received: November 18, 2015; Accepted: March 8, 2016; Published Online: August 31, 2016

Citation: Pietrzak K, Otlewska A, Puchalski M, et al. 2016, Antimicrobial properties of silver nanoparticles against biofilm formation by Pseudomonas aeruginosa on archaeological textiles. Applied Environmental Biotechnology, vol.1(2): 1-9.

http://dx.doi.org/10.18063/AEB.2016.02.001.

\section{Introduction}

$\mathrm{F}$ or thousands of years, textiles have played a key role in the social, economic, and ideological life of the Andean world populations.
"Every nation that inhabited this universe dressed according to their symbols, expressed with its own iconography, with a particular manufacturing, colour, and style that set her apart from the others and indicating their cultural identity and landscape from where

Antimicrobial properties of silver nanoparticles against biofilm formation by Pseudomonas aeruginosa on archaeological textiles (C 2016 Katarzyna Pietrzak, et al. This is an Open Access article distributed under the terms of the Creative Commons Attribution-NonCommercial 4.0 International License (http://creativecommons.org/licenses/by- nc/4.0/), permitting all non-commercial use, distribution, and reproduction in any medium, provided the original work is properly cited. 
they belonged" ${ }^{\prime[1]}$. The textiles dating from the preand post-Columbian times were made mainly from wool and cotton. The designs included geometrical patterns, representations of gods, men, plants, animals, and supernatural beings.

Archaeological textiles in suitable conditions (high humidity, high temperature, and presence of organic substances) may be overgrown with microorganisms, which cause the weakening or loosening of structure, odour emission, aesthetic changes, the presence of staining and discolorations on the surface, slimy substances, and finally complete deterioration ${ }^{[2-6]}$. The biodeterioration of archaeological textiles may have important economic and cultural consequences. The colonisation and development of biofilms formed by fungi and bacteria drastically modify the material. Biofilms are aggregates of microorganisms encased in their matrix of extracellular polymeric substances (EPS). These EPS consist of a mixture of polysaccharides, proteins, nucleic acids, and other highly hydrated biopolymers. Microorganisms such as fungi (i.e., Cladosporium sp.) and bacteria (Pseudomonas sp.), which form biofilm on textiles also cause the degradation of cellulose or proteins - the main component of natural fibres such as cotton and wool ${ }^{[7]}$. Proper storage of textiles in special containers, under suitable and stable conditions of light $(<50$ lux $)$, temperature $\left(18-20^{\circ} \mathrm{C}\right)$, and relative humidity $(<55 \%)$ is effective to avoid undesirable results ${ }^{[8-10]}$. The most effective method to inhibit the biodeterioration is disinfection (the destruction of pathogenic and saprophytic microorganisms and their spores by physical or chemical agents). Chemical agents used in disinfection include quaternary ammonium salts, ethylene oxide, alcohols, aldehydes such as formaldehyde, glutaraldehyde, phenolic compounds, biguanides, halogen compounds, dyes, peroxides, surfactants, heavy metals (e.g., $\mathrm{Ag}, \mathrm{Cu}, \mathrm{Au})^{[11]}$. The most common method for disinfection of historical objects is ethylene oxide; its high effectiveness is incomparable with any other fumigant. Unfortunately it is a carcinogenic, mutagenic gas, causing allergic reactions and having an irritating action on the respiratory tract $\mathrm{t}^{[12,13]}$.

In the past few years, there has been increasing interest in silver nanoparticles (AgNPs), due to its high antimicrobial properties ${ }^{[14,15]}$. Previous studies performed by Gutarowska et al. show that silver nanoparticles in the form of mist are effective in disinfection of historical materials such as textiles, paper, leather and wood ${ }^{[16]}$. AgNPs misting reduced bacterial number by $87 \%-99 \%$ and fungal by $32 \%-54 \%$ on cotton fabrics. Moreover, AgNPs misting protection method does not significantly influence the optical and mechanical properties of cotton fabrics, even after accelerated light ageing ${ }^{[17]}$.

So far, there are no studies concerning the use of silver nanoparticles for inhibition of biofilm formation on archaeological textiles. The objectives of this study were to: (i) analyse the pre- and post-Columbian archaeological textiles microscopically; (ii) analyse the archaeological textiles microbiologically; (iii) determine the ability of Pseudomonas sp. isolates from textiles for its biofilm formation; (iv) assess the anti-biofilm properties of cotton protected-AgNPs from Pseudomonas sp.

\section{Materials and Methods}

\subsection{Characterisation of the Samples}

The tested samples came from the pre-Columbian archaeological textiles (1250-1450 AD) from the Southern Andean area. The samples came from excavations in the Puna Argentina, Santa Rosa de Tastil, performed between 1967 and 1969, and guided by Diana Rolandi ${ }^{[18]}$. They are sheltered in Deposit 25 of Archaeological Division at La Plata Museum. Sample 1 was made of cotton, while samples 2 and 3 were made of wool.

\subsection{Microscopic Analysis of Archaeological Textiles}

The microscopic analysis of surface modified fabrics were carried out by means of scanning electron microscope (SEM) Nova NanoSEM 230 from FEI company (SE Detector, HV: $15 \mathrm{kV}$, Low Vacuum) with $\mathrm{X}$-ray microanalyser EDX (Energy-dispersive X-ray Spectroscopy) (EDAX, USA). The quantitative chemical analysis of studied materials was carried out by the use of ViP Quant software with ZAF and low vacuum correction procedures. The samples were prepared by fixing the fabric to holder with the aid of conductive carbon adhesive tape.

\subsection{Microbial Contamination of Archaeological Textiles}

Sampling was done from $1 \mathrm{~cm}^{2}$ surface of the textiles using sterile cotton swabs ${ }^{[19]}$. Proteolytic, amylolytic, and lipolytic bacteria were counted in differential culture media ${ }^{[20,21]}$. Proteolytic activity was determined on Frazier Gelatin Agar $\left(\right.$ Merck $^{\circledR}$, Germany/Britania ${ }^{\circledR}$, Argentina). Amylolytic activity was determined on 
Starch Agar (DifcoTM, USA/Britania ${ }^{\circledR}$, Argentina) by addition of Lugol's reagent. Lipolytic activity was determined on Tributiryn Agar (Fluka/Britania ${ }^{\circledR}$, Argentina). All samples were incubated at $28^{\circ} \mathrm{C} \pm 2$ for 3 days. The colonies were counted and expressed as $\mathrm{CFU} / \mathrm{cm}^{2}$.

The presence of sulphite-reducing bacteria from genus Clostridium sp. was checked by inoculation of aliquots into differential-reinforced Clostridium broth (DRCM Merck ${ }^{\circledR}$, Germany) and incubated at $28^{\circ} \mathrm{C} \pm 2$ for 15 days in anaerobic conditions ${ }^{[22]}$. All samples were done in duplicates.

The Pseudomonas sp. strains were grown on blood agar $\left(\mathrm{Oxoid}^{\circledR}, \mathrm{UK}\right)$ and Cetrimide agar $\left(\mathrm{Merck}^{\circledR}\right.$, Germany). The phenotypic method for detecting metallo-ß-lactamases was done using a commercially available screen kit (RCS) (Rosco Diagnostica A/S, Taastrup, Denmark $)^{[23]}$ and incubated at $36^{\circ} \mathrm{C}$ for $24 \mathrm{~h}$.

Bacteria were typified according to the Gram staining and biochemical tests described in Bergey's Manual of Systematic Bacteriology ${ }^{[24]}$. One of the strains of Pseudomonas sp. was typified as Pseudomonas aeruginosa (strain 1) while the other one as Pseudomonas sp. (strain 2). For molecular identification, two Pseudomonas sp. strains were chosen due to its ability to form biofilm. For further studies, two Pseudomonas strains were selected for laboratory studies due to its bioadhesion ability, pigment production, and viability and growth on textile fibres.

\subsection{Molecular Identification of Pseudomonas sp. Isolates}

Molecular identification of two Pseudomonas sp. strains isolated from archaeological textiles was performed according to methodology presented by Kręgiel et al. ${ }^{[25]}$. The nucleotide sequences of $16 \mathrm{~S}$ ribosomal RNA gene were deposited in GeneBank NCBI database with accession numbers: KP842564 (strain no. 1) and KP842565 (strain no. 2). Both strains were also deposited in Pure Culture Collection at the Institute of Fermentation Technology and Microbiology at Lodz University of Technology ( $\mathrm{EOCK}$ ) with accession numbers: ŁOCK 0998 (strain no. 1) and ŁOCK 0999 (strain no. 2).

\subsection{Bioadhesion and Biofilm Formation Assay}

Bacterial strains were inoculated on solid Mineral Medium $^{[5]}$ on agar slant with samples of archaeological textiles as a sole carbon source. The bioadhesion and biofilm formation were assessed after $72 \mathrm{~h}$ of bacterial incubation using scanning electron microscope (SEM) (FEI Quanta200). Samples were kept in a closed chamber with ethanol $(100 \%)^{[26]}$ for $24 \mathrm{~h}$ and metalised with $\mathrm{Au} / \mathrm{Pd}$ prior to microscopic observation.

\subsection{Preparation of Silver Nanoparticles}

Colloidal silver nanoparticles (produced by Mint Metale Szlachetne S.A., Poland) were prepared at a concentration of $90 \mathrm{ppm}$; particle sizes of $10-15 \mathrm{~nm}$ $(60 \%-70 \%)$ and $50-80 \mathrm{~nm}(30 \%-40 \%)$. The process was undertaken in a chamber $\left(1.73 \mathrm{~m}^{3}\right)$, temperature $\mathrm{T}=25^{\circ} \mathrm{C}, \mathrm{RH}=90 \%$, air flow $1 \mathrm{~m} / \mathrm{s}$. The process lasted $8 \mathrm{~h}$ ( 8 disinfection cycles). The chamber and disinfection procedure are patent protected (Polish Patent no. $\mathrm{P}-399$ 507) ${ }^{[27]}$. The disinfection chamber, the silver nanoparticle colloid preparation and its application are described in detail in previous study ${ }^{[28]}$. The amount of silver nanoparticles deposited on the cotton fabric during one disinfection process, established using the FAAS (Flame Atomic Absorption Spectroscopy) method, was $4.5 \mathrm{ppm} / \mathrm{g}$. The chosen disinfection parameters ensure the safeness for the treated textile samples $^{[16]}$.

\subsection{Antibacterial Properties of AgNPs against Pseudomonas aeruginosa on Textile Samples}

Model of the studies were performed on cotton to assess the ability of AgNPs to inhibit Pseudomonas sp. growth. Cotton fabrics were supplied by Andropol S.A. (Poland). The characteristics of this fabric are given in the previous article ${ }^{[17]}$. Fabric were also analysed in terms of colour changes due to bacterial growth.

The cotton samples were antimicrobially protected by misting with silver nanoparticles preparation (90 ppm, 8 misting cycles) ${ }^{[29]}$. They were placed on the Petri dishes with Mineral Medium ${ }^{[5]}$.The inoculum concentrations of Pseudomonas aeruginosa were established using culture method, with equalled $10^{8} \mathrm{CFU} / \mathrm{mL}$ for both strains. The inocula $(100 \mu \mathrm{L})$ were applied on cotton samples with AgNPs and incubated for 5 days in a climatic chamber, KBF720 (Binder GmbH, Germany), at $\mathrm{T}=28^{\circ} \mathrm{C}$ and $\mathrm{RH}=80 \%$. After 0,3 and 5 days, the number of microorganisms was determined by AATCC 100:2012 test method ${ }^{[30]}$. Each sample were placed in $50 \mathrm{~mL}$ of sterile saline $(0.85 \%$ $\mathrm{NaCl})$ and shaken for $20 \mathrm{~min}(200 \mathrm{cpm}$; ELPIN+ S.C. 358A, Poland). Then, using serial dilutions, the number of microorganisms in $\mathrm{CFU} / \mathrm{cm}^{2}$ was determined on TSA (Tryptic Soy Agar, Merck, Germany). Each strain had its own control (without AgNPs). Samples were 
done in triplicate. The arithmetic mean and standard deviation of the number of microorganisms on cotton with and without silver nanoparticles were calculated. The reduction, $\mathrm{R}(\%)$ in the number of microorganisms on cotton with AgNPs was determined using the following equation:

$$
R=\frac{N_{0}-N}{N_{0}} \times 100 \%
$$

where:

$N$ is the number of microorganisms on the sample with AgNPs (CFU per sample);

$N_{0}$ is the number of microorganisms on the sample without AgNPs (CFU per sample).

An ANOVA statistical analysis was performed to assess the statistically significant difference between the number of microorganisms on cotton with and without AgNPs.

\section{Results and Discussion}

The SEM-EDX technique can be used for fibre identification of archaeological textiles even when the fabric is almost completely mineralised ${ }^{[31]}$. The analysis of pre- and post-Columbian textiles (samples 1, 2, and 3) showed high content of carbon (1: $40.81 \% ; 2$ : $46.19 \%$; 3: $55.01 \%, \mathrm{w} / \mathrm{w})$, which proves that natural fibres are good carbon source for microorganisms. Samples made of wool (2 and 3$)$ were also rich in sulphur (2: $2.17 \% ; 3: 2.39 \%, w / w)$ and sample 3 was also rich in nitrogen $(9.62 \%, \mathrm{w} / \mathrm{w})$. The presence of other compounds showed that the tested fabrics were mineralised and highly contaminated with sand and salts. Moreover, iron was detected on sample $1(1.81 \%$, $\mathrm{w} / \mathrm{w})$ (Figure 1), which may be related to respiratory activity of anaerobic bacteria. It might be the causes of reddish spots (foxing type) on textiles, as a result of oxidation processes.

The determined number of lipolytic bacteria $(3 \times$ $10^{4}-3 \times 10^{6} \mathrm{CFU} / \mathrm{cm}^{2}$ ) was high, while there was low concentration of proteolytic bacteria $\left(1-4 \mathrm{CFU} / \mathrm{cm}^{2}\right)$ (Figure 2). Amylolytic bacteria were not detected at any of the tested samples.

The mechanism of microbial degradation of textiles depends on their chemical composition. Cotton (cellulose-based fabrics) is damaged by enzymatic hydrolysis $(1,4-$ endo- $\beta$-D-glucan cellobiohydrolase, endo-1-4- $\beta$-D-glucan glucanohydrolase, glucohydrolase of $\beta$-D-glucosides ${ }^{[32-34]}$. The microorganisms responsible for cellulose-based fibres degradation are mostly fungi (Alternaria sp., Aspergillus sp., Aureobasidium sp., Chaetomium sp., Mucor sp., Penicillium sp., Rhizopus sp., Trichoderma sp.). However, bacteria also
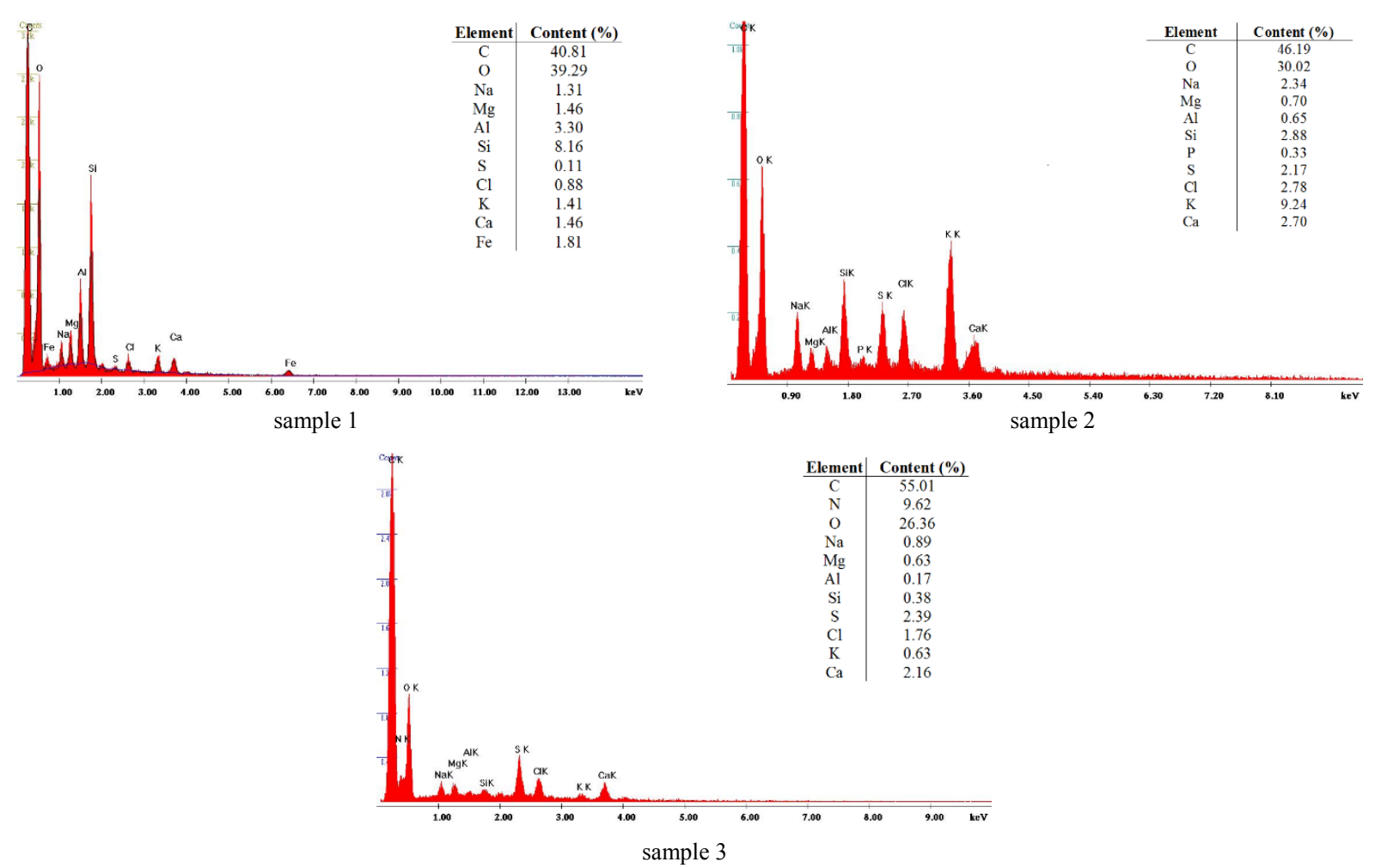

Figure 1. Element content on archaeological textiles (SEM-EDX). 


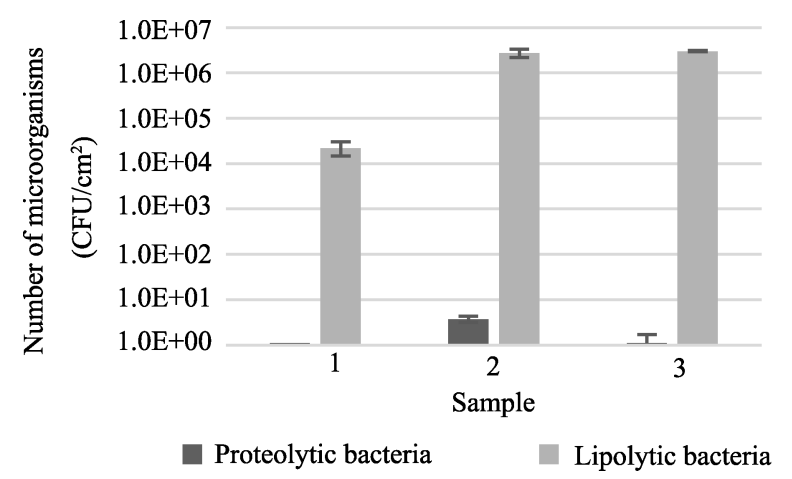

Figure 2. Bacterial contamination of archaeological samples.

play a significant role (Bacillus sp., Cellulomonas sp., Cellvibrio sp., Clostridium sp., Pseudomonas sp., Streptomyces sp. ${ }^{[35,36]}$.

The wool is characterised by high content of various amino acids. The keratinolysis process is the result of three reactions: sulfitolysis, proteolysis and deamination ${ }^{[34,37]}$. Microorganisms known from literature for wool biodeterioration activity are bacteria such as Alkaligenes bookeri, Pseudomonas aeruginosa, Proteus vulgaris, Bacillus sp. (B. agri, B. mycoides, B. mesentericus, B. megatherium, B. subtilis) and fungi, namely Aspergillus sp., Alternaria sp., Cephalothecium sp., Dematium sp., Fusarium sp., Oospora sp., Penicillium sp. and Trichoderma $\mathrm{sp}^{[36]}$.
Among the microorganisms inhabiting tested archaeological textiles were Clostridium sp. and Pseudomonas sp., which are known for archaeological textiles colonisation ${ }^{[37]}$. The literature data show that Clostridium genus can produce textile degrading enzymes such as lipases ${ }^{[21,38]}$.

Isolated Pseudomonas strains grow as bright yellow slimy colonies and produce pigments changing the colour of cotton fibres (Figure 3). Pseudomonas sp. strain no. 1 produces a bluish-green pigment, a typical for Pseudomonas aeruginosa, while Pseudomonas sp. strain no. 2 produces brown pigment and colonies glow in UV light (Figure 4). Using the molecular methods, both strains of Pseudomonas sp. were identified as Pseudomonas aeruginosa.

Pseudomonas aeruginosa strain 1 show the adherence to the archaeological textiles and SEM analysis proved its bioadhesion ability and biofilm formation (Figure 5). They also exhibited proteolytic and lipolytic properties in culture media, which confirms with previous studies ${ }^{[5]}$. Microorganisms inhabit the material due to its natural composition and sufficient moisture content, adhering to the textile that develops biofilms. The microbial growth and its metabolites cause structural damages, which are a hazard for the fibres $^{[7]}$.

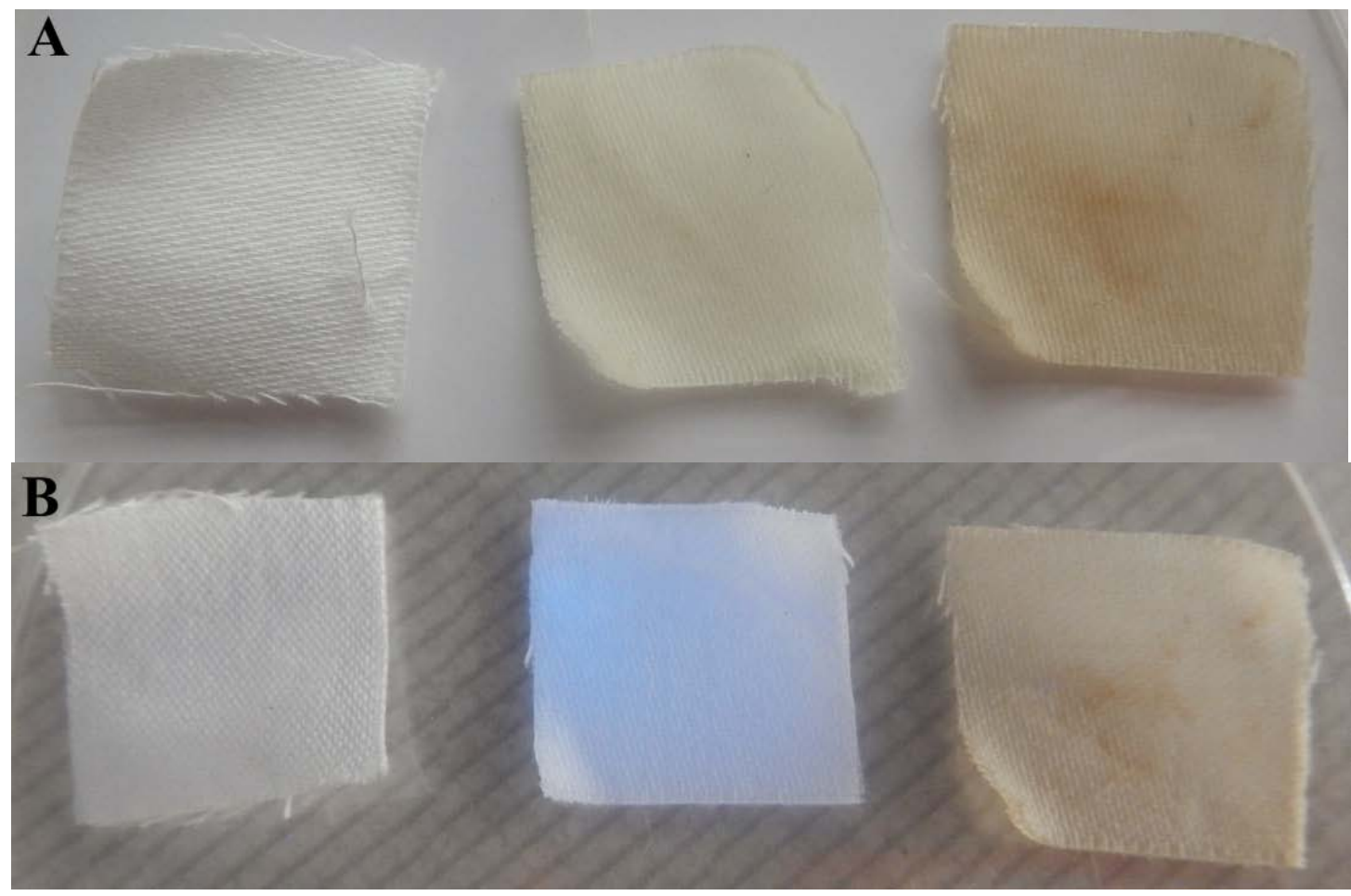

Figure 3. Pseudomonas aeruginosa growing on cotton samples. (A) Daylight; (B) UV light; Left: control; Centre: strain no. 1; Right: strain no. 2. 


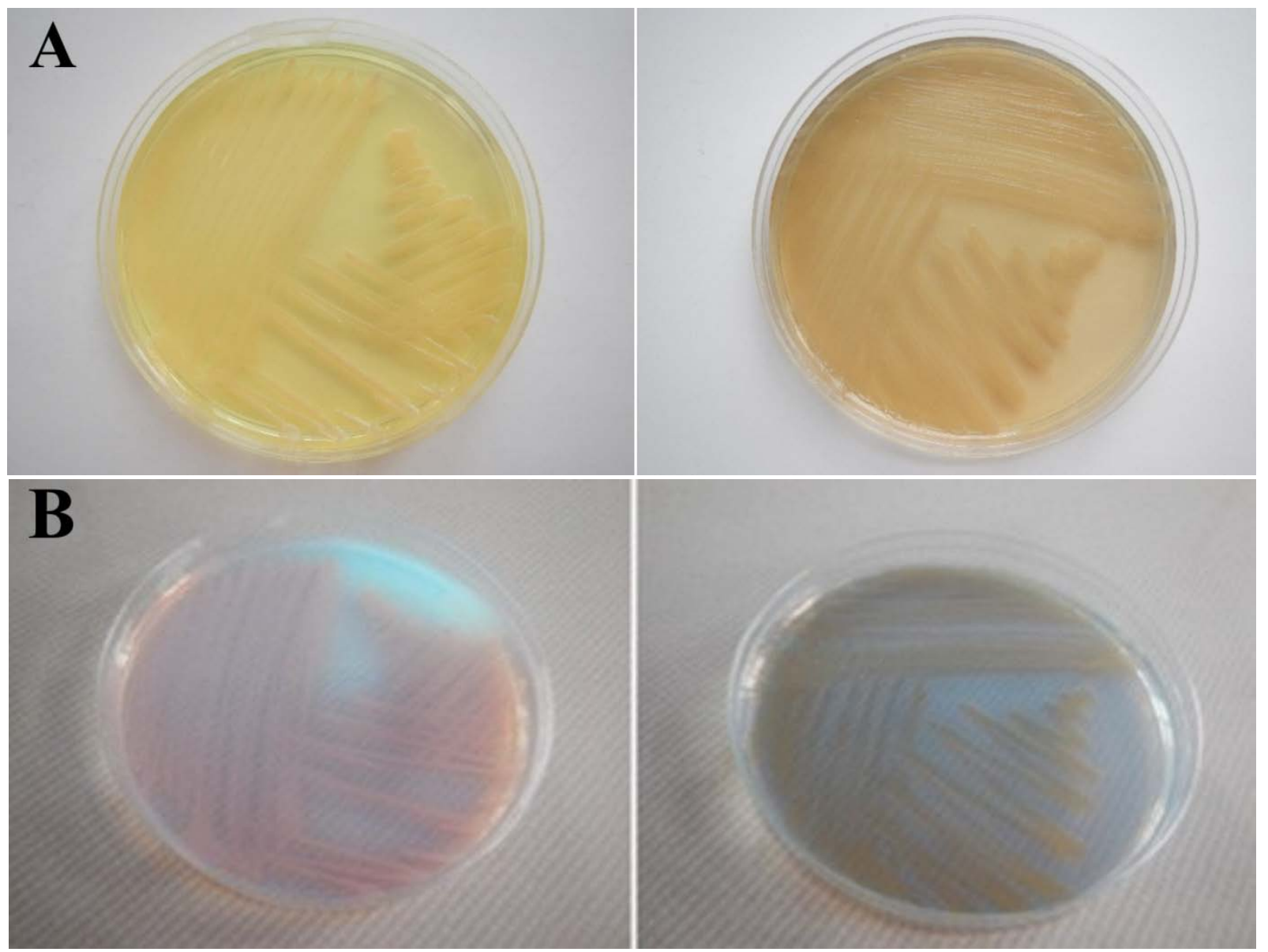

Figure 4. Pseudomonas aeruginosa on tryptic soy agar. (A) Daylight; (B) UV light; Left: strain no. 1; Right: strain no. 2.
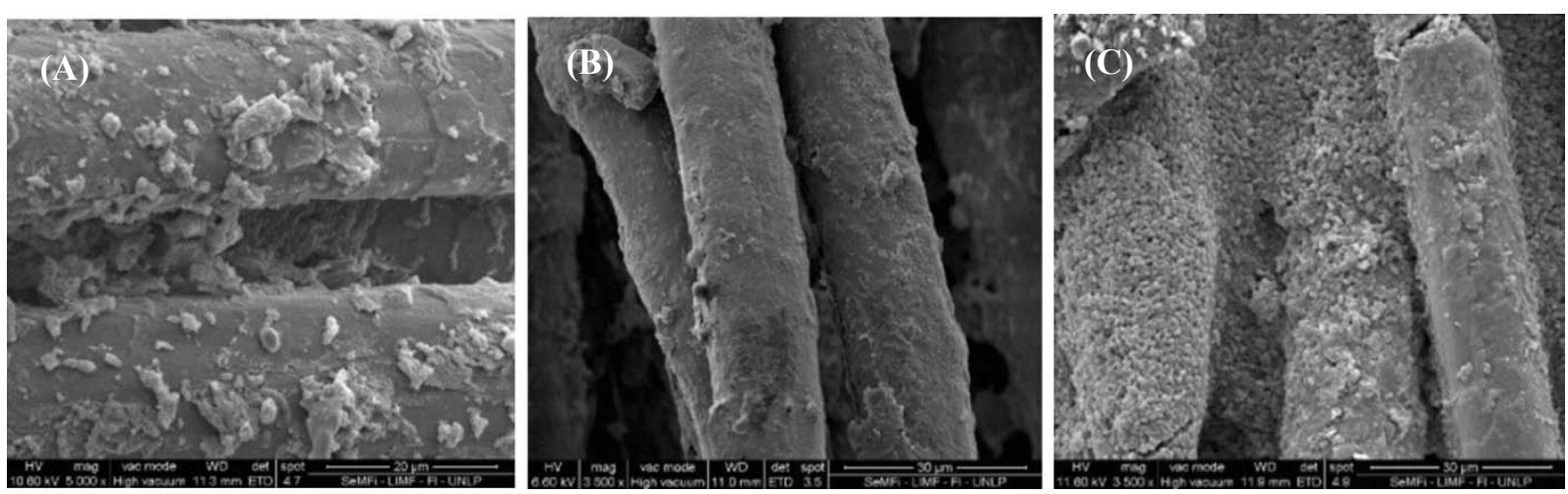

Figure 5. SEM images of: (A) Archaeological textile sample with adhered bacteria and material dirt (5000X, Bar $20 \mu \mathrm{m})$; (B) Adhered Pseudomonas aeruginosa (strain 1) and biofilm formed on archaeological textile fibre (72 h); (C) Adhered Pseudomonas aeruginosa (strain 2) on archaeological textile fibre $(72 \mathrm{~h})$.

Microbiological analyses proved various abilities for microbial growth on cotton for both tested strains. Number of Pseudomonas aeruginosa strain 1 increased during the incubation on control cotton sample from $1.5 \times 10^{6} \mathrm{CFU} / \mathrm{cm}^{2}$ to $3.6 \times 10^{7} \mathrm{CFU} / \mathrm{cm}^{2}$ on day 5 of incubation time. On the other hand, the amount of Pseudomonas aeruginosa strain 2 decreased during the incubation from $4.3 \times 10^{5} \mathrm{CFU} / \mathrm{cm}^{2}$ to $4.3 \times 10^{4} \mathrm{CFU} / \mathrm{cm}^{2}$ (Table 1, control samples). Strain 1 has a greater ability to form biofilms on cotton than strain 2, which proves the observations from SEM analysis. 
Table 1. Pseudomonas aeruginosa growth on cotton samples with/without AgNPs

\begin{tabular}{|c|c|c|c|c|c|c|}
\hline \multirow{3}{*}{ Day } & \multicolumn{6}{|c|}{ Number of microorganisms $\left(\mathrm{CFU} / \mathrm{cm}^{2}\right)$} \\
\hline & \multicolumn{3}{|c|}{ Pseudomonas aeruginosa strain 1} & \multicolumn{3}{|c|}{ Pseudomonas aeruginosa strain 2} \\
\hline & Control without AgNPs & AgNPs & $\mathrm{R}(\%)$ & Control without AgNPs & AgNPs & $\mathrm{R}(\%)$ \\
\hline \multirow{2}{*}{0} & M: $1.5 \times 10^{6}$ & M: $1.2 \times 10^{6}$ & \multirow{2}{*}{21.5} & M: $4.3 \times 10^{5}$ & M: $6.4 \times 10^{5}$ & \multirow{2}{*}{ - } \\
\hline & SD: $7.0 \times 10^{5}$ & SD: $3.1 \times 10^{5}$ & & SD: $1.6 \times 10^{5}$ & SD: $2.6 \times 10^{4}$ & \\
\hline \multirow{2}{*}{3} & M: $1.1 \times 10^{7}$ & M: $6.3 \times 10^{6^{*}}$ & \multirow{2}{*}{43.0} & M: $5.0 \times 10^{4}$ & M: $5.0 \times 10^{4}$ & \multirow{2}{*}{-} \\
\hline & SD: $4.6 \times 10^{6}$ & SD: $2.5 \times 10^{6}$ & & SD: $2.0 \times 10^{4}$ & SD: $2.0 \times 10^{4}$ & \\
\hline \multirow{2}{*}{5} & M: $3.6 \times 10^{7}$ & M: $1.3 \times 10^{7 *}$ & \multirow{2}{*}{62.9} & M: $4.3 \times 10^{4}$ & M: $6.3 \times 10^{2^{*}}$ & \multirow{2}{*}{97.1} \\
\hline & SD: $2.5 \times 10^{7}$ & SD: $1.7 \times 10^{7}$ & & SD: $1.6 \times 10^{4}$ & SD: $3.2 \times 10^{3}$ & \\
\hline
\end{tabular}

M: arithmetic mean; SD: standard deviation; -: no reduction

*: significantly different to the sample without AgNPs, ANOVA with significance level $p<0.05$

The silver nanoparticles inhibited the growth of both Pseudomonas strains. For strain 1, the maximum decrement in the microorganisms number was from $3.6 \times 10^{7} \mathrm{CFU} / \mathrm{cm}^{2}$ to $1.3 \times 10^{7} \mathrm{CFU} / \mathrm{cm}^{2}$, which constituted up to $63 \%$ (day 5). For strain 2, the maximum decrement in the microorganisms number was higher and reached $97 \%$ (day 5) - from $4.3 \times 10^{4}$ to $6.3 \times 10^{2} \mathrm{CFU} / \mathrm{cm}^{2}$. The differences between number of microorganisms with and without nanosilver are significantly different after 5 days of incubation for both strains and after 3 days for strain 1, respectively (Table 1, AgNPs samples).

Pseudomonas aeruginosa is known for its resistance to antibiotics and several antimicrobial agents. The literature shows that AgNPs can be very efficient in limiting $P$. aeruginosa biofilm formation, however, it happens only when there is a direct contact of nanoparticles with the bacterial cells (biofilm and planktonic) in liquid culture. A number of studies show very high reduction of $P$. aeruginosa biofilm, up to $100 \%$, due to AgNPs action ${ }^{[39-41]}$. The data obtained in this study for microbial number reduction is lower (up to $2 \log$ units for strain 2). However, on the textiles there is no direct contact of microorganisms with the silver nanoparticles; thus, it is impossible to achieve very high disinfection effectiveness without material destruction. Literature shows no studies presenting the limitation of Pseudomonas aerugino$s a$ biofilm on archaeological textiles. On the other hand, studies considering the influence of biocides on new textiles for $P$. aeruginosa are unfortunately not promising. Jakimiak et al. ${ }^{[42]}$ tested cotton finished with quaternary ammonium compounds, while Takai et al. ${ }^{[43]}$ tested textiles (cotton, polyester/cotton) with different antibacterial finishing substances (Ag.Zn.Cu - Zeolite; Ag.Zn.ammonium Zeolite; aliphatic imide; quaternary ammonium derivative; chitosan). Both research teams observed absence of antimicrobial effect against $P$. aeruginosa (pure culture collection and wild strains). Such results suggested that the data presented in the study of silver nanoparticles misting can be very promising in the antimicrobial protection of textiles, especially those related to archaeological textiles.

\section{Conflict of Interest and Funding}

No conflict of interest was reported by all authors. The work was supported by National University of La Plata (UNLP) Incentive Projects $11 \mathrm{~N} 713$, and the National Council of Scientific and Technical Research PIP 0200 (CONICET).

\section{Acknowledgements}

The authors would like to thank Ana Igareta for allowing the microbial sampling in Deposit 25, Archaeological Division at La Plata Museum, and Lic. Patricia Battistoni for the technical support.

\section{References}

1. Raffino R, 2002, Arte textil de la civilización andina (Colección Museo de La Plata), in Corpus Antiquitatum Americanensium, Prólogo, Tomo 4, Academia Nacional de la Historia-Union Academique Internationale, Buenos Aires, 10.

2. Strzelczyk A B, 2004, Observations on aesthetic and structural changes induced in Polish historic objects by microorganisms. International Biodeterioration and Biodegradation, vol.53(3): 151-156. http://dx.doi.org/10.1016/S0964-8305(03)00088-X.

3. Szostak-Kotowa J, 2004, Biodeterioration of textiles. International Biodeterioration and Biodegradation, vol.53(3): 165-170. http://dx.doi.org/10.1016/S0964-8305(03)00090-8. 
4. Michaelsen A, Pinzari F, Ripka K, et al. 2006, Application of molecular techniques for identification of fungal communities colonizing paper material. International Biodeterioration and Biodegradation, vol.58(3-4): 133-141. http://dx.doi.org/10.1016/j.ibiod.2006.06.019.

5. Lavin P, Gómez de Saravia S G and Guiamet P S, 2014, An environmental assessment of biodeterioration in document repositories. Biofouling: The Journal of Bioadhesion and Biofilm Research, vol.30(5): 561-569. http://dx.doi.org/10.1080/08927014.2014.897334.

6. Guiamet P, Pietrzak K, Gutarowska B, et al. 2015, Textiles de la puna argentina. Identifcación del biodeterioro a través de diferentes técnicas. IV Jornadas para el estudio de Bienes Culturales, 44-45.

7. Guiamet P, Igareta A, Battistoni P, et al. 2014, Fungi and bacteria in the biodeterioration of archaeological fibers. Analysis using different microscopic techniques. Revista Argentina de Microbiología, vol.46(4): 376-377. http://dx.doi.org/10.1016/S0325-7541(14)70097-5.

8. Wolf S J, 2002, Appendix K: curatorial care of textile objects, in NPS Museum Handbook, Part I. National Park Service, USA.

9. Éri I, 2004, Conserving Textiles: Studies in Honour of Agnes Timár-Balázsy. ICCROM International Centre for the Study of the Preservation and Restoration of Cultural Property, Rome.

10. Sterflinger K, 2010, Fungi: their role in deterioration of cultural heritage. Fungal Biology Reviews, vol.24(1-2): 47-55. http://dx.doi.org/10.1016/j.fbr.2010.03.003.

11. Rutala W A and Weber D J, 1999, Infection control: the role of disinfection and sterilization. Journal of Hospital Infection, vol.43(Supplement 1): S43-S55. http://dx.doi.org/10.1016/S0195-6701(99)90065-8.

12. Rakotonirainy M S, Fohrer F and Flieder F, 1999, Research on fungicides for aerial disinfection by thermal fogging in libraries and archives. International Biodeterioration and Biodegradation, vol.44(2-3): 133-139. http://dx.doi.org/10.1016/S0964-8305(99)00075-X.

13. Rakotonirainy M S and Lavédrine B, 2005, Screening for antifungal activity of essential oils and related compounds to control the biocontamination in libraries and archives storage areas. International Biodeterioration and Biodegradation, vol.55(2): 141-147. http://dx.doi.org/10.1016/j.ibiod.2004.10.002.

14. Kim J S, Kuk E, Yu K N, et al. 2007, Antimicrobial effects of silver nanoparticles. Nanomedicine: Nanotechnology, Biology, and Medicine, vol.3(1): 95-101. http://dx.doi.org/10.1016/j.nano.2006.12.001.

15. Rai M, Yadav A and Gade A, 2009, Silver nanoparticles as a new generation of antimicrobials. Biotechnology Advances, vol.27(1): 76-83.

http://dx.doi.org/10.1016/j.biotechadv.2008.09.002.
16. Gutarowska B, Pietrzak K, Machnowski W, et al. 2014, Application of silver nanoparticles for disinfection of materials to protect historical objects. Current Nanoscience, vol.10(2): 277-286.

http://dx.doi.org/10.2174/15734137113096660121.

17. Pietrzak K, Gutarowska B, Machnowski W, et al. 2015, Antimicrobial properties of silver nanoparticles (AgNPs) misting on cotton fabrics. Textile Research Journal, vol.86(8): 812-822. http://dx.doi.org/10.1177/0040517515596933.

18. Rolandi de Perrot D S, 1972, Estudio sobre textiles del yacimiento arqueológico de santa Rosa de Tastil, Salta. Doctoral Thesis. Universidad Nacional de La Plata, Argentina.

19. Pinzari F, Montanari M, Michaelsen A, et al. 2010, Analytical protocols for the assessment of biological damage in historical documents. Coalition, vol.19: 6-13.

20. Borrego S, Guiamet P, Gómez de Saravia S, et al. 2010, The quality of air at archives and the biodeterioration of photographs. International Biodeterioration and Biodegradation, vol.64(2): 139-145.

http://dx.doi.org/10.1016/j.ibiod.2009.12.005.

21. Guiamet P, Borrego S, Lavin P, et al. 2011, Biofouling and biodeterioration in materials stored at the Historical Archive of the Museum of La Plata, Argentine and at the National Archive of the Republic of Cuba. Colloids and Surfaces B: Biointerfaces, vol.85(2): 229-234. http://dx.doi.org/10.1016/j.colsurfb.2011.02.031.

22. Madigan M T, Martinko J M, Dunlap P V, et al. 2009, Brock Biology of Microorganisms, $12^{\text {th }}$ edition, Benjamin Cummings, San Francisco, USA.

23. Dortet L, Poirel L and Nordmann P, 2012, Rapid detection of carbapenemase-producing Pseudomonas spp. Journal of Clinical Microbiology, vol.50(11): 3773-3776. http://dx.doi.org/10.1128/JCM.01597-12.

24. Sneath P, Mair N and Sharpe M (eds), 1986, Bergey's Manual of Systematic Bacteriology, Volume 2, Williams and Wilkins, Baltimore, MD, USA.

25. Kregiel D, Otlewska A and Antolak H, 2014, Attachment of Asaia bogorensis originating in fruit-flavored water to packaging materials. BioMed Research International, Article ID 514190, 6 pages.

http://dx.doi.org/10.1155/2014/514190.

26. Lavin P, Gómez de Saravia S and Guiamet P, 2016, Scopulariopsis sp. and Fusarium sp. in the documentary heritage: evaluation of their biodeterioration ability and antifungal effect of two essential oils. Microbial Ecolo$g y$, vol.71(3): 628-633. http://dx.doi.org/10.1007/s00248-015-0688-2.

27. Wasiak R, Laskowski Z and Czyzyk J, 2012, The microbiological protection method of archive and museum objects and installation for the microbiological protection of archive and museum objects. Patent PL399507, 
Poland.

28. Gutarowska B, Skóra J, Zduniak K, et al. 2012, Analysis of the sensitivity of microorganisms contaminating museums and archives to silver nanoparticles. International Biodeterioration and Biodegradation, vol.68: 7-17. http://dx.doi.org/10.1016/j.ibiod.2011.12.002.

29. Gutarowska B, Rembisz D, Zduniak K, et al. 2012, Optimization and application of the misting method with silver nanoparticles for disinfection of the historical objects. International Biodeterioration and Biodegradation, vol.75: 167-175.

http://dx.doi.org/10.1016/j.ibiod.2012.10.002.

30. AATCC Test Method 100-2012. Antibacterial finishes on textile materials: assessment of final report: R2014-295-2, 2014, viewed on November 3, 2015, $<$ https://drywired.com/wp-content/uploads/2015/07/Text ile_Bacteria.pdf $>$

31. Timár-Balázsy A and Eastop D, 1998, Chemical Principles of Textile Conservation, Routledge, New York.

32. Evans E T, 1996, Biodegradation of cellulose. Biodeterioration Abstracts, vol.10(30): 275-285.

33. Jeffries T W, 1987, Physical, chemical and biochemical considerations in the biological degradation of wood, in Kennedy J F, Phillips G O, Williams P A (eds), Wood and Cellulosics: Industrial Utilization, Biotechnology, Structure and Properties. Ellis Horwood Limited, Chichester, p.213.

34. Szostak-Kotowa J, 2005, Fibres and nonwovens, in Zyska B, Żakowska Z (eds), Microbiology of Materials. Technical University of Lodz, Lodz, pp.89-136, Polish.

35. Flannigan B, Samson R A and Miller J D, 2001, Microorganisms in Home and Indoor Work Environments: Diversity, Health Impacts, Investigation and Control, Taylor and Francis, London/New York.

36. Pekhtasheva E, Neverov A, Kubica S, et al. 2012, Bio- degradation and biodeterioration of some natural polymers. Chemistry and Chemical Technology, vol.6(3): 263-280.

37. Błyskal B, 2009, Fungi utilizing keratinous substrates. International Biodeterioration and Biodegradation, vol.63(6): 631-653. http://dx.doi.org/10.1016/j.ibiod.2009.02.006.

38. Ágoston-Szabó E, Dinka M, Némedi L, et al. 2006, Decomposition of Phragmites australis rhizome in a shallow lake. Aquatic Botany, vol.85(4): 309-316. http://dx.doi.org/10.1016/j.aquabot.2006.06.005.

39. Kalishwaralal K, BarathManiKanth S, Pandian S R K, et al. 2010, Silver nanoparticles impede the biofilm formation by Pseudomonas aeruginosa and Staphylococcus epidermidis. Colloids and Surfaces B: Biointerfaces, vol.79(2): 340-344. http://dx.doi.org/10.1016/j.colsurfb.2010.04.014.

40. Palanisamy N K, Ferina N, Amirulhusni A N, et al. 2014, Antibiofilm properties of chemically synthesized silver nanoparticles found against Pseudomonas aeruginosa. Journal of Nanobiotechnology, vol.12: 2. http://dx.doi.org/10.1186/1477-3155-12-2.

41. Königs A M, Flemming H C and Wingender J, 2015, Nanosilver induces a non-culturable but metabolically active state in Pseudomonas aeruginosa. Frontiers in Microbiology, vol.6: 395. http://dx.doi.org/10.3389/fmicb.2015.00395.

42. Jakimiak B, Röhm-Rodowald E, Staniszewska M, et al. 2006, Microbiological assessment of efficiency of antibacterial modified textiles. Roczniki Państwowego Zakładu Higieny, vol.57(2): 177-184.

43. Takai K, Ohtsuka T, Senda Y, et al. 2002, Antibacterial properties of antimicrobial-finished textile products. Microbiology and Immunology, vol.46(2): 75-81. http://dx.doi.org/10.1111/j.1348-0421.2002.tb02661.x. 